\title{
The BBC, Austerity and Broadcasting the 1948 Olympic Games \\ Richard Haynes
}

\author{
The International Journal of the History of Sport, Vol. 27, No. 6, April
}

2010, 1025-1042. ISSN: 0952-3367

\begin{abstract}
Based on original archive research, including papers held in the BBC Written Archives Centre, and interviews with those involved, this paper analyses the historical importance for the BBC of the 1948 Games as the first publicly televised Olympics. In particular, the paper addresses the management of operations by the Head of Outside Broadcasting at the BBC, Seymour Joly de Lotbiniere. De Lotbiniere had been an important figure in the development of outside broadcasting commentaries during the inter-war period and was given the task of organising the radio and television coverage of the London Games in 1948. The paper examines the technical, operational and ideological issues raised by the event for the $\mathrm{BBC}$ and its legacy for the development of live televised outside broadcasts from sport. The analysis suggests the BBC's ability to host international broadcasters became a matter of prestige and its forays into television a sign of its emerging post-War modernity.
\end{abstract}

"We believe that the Games will end being a very big 'story' and that a

sufficiency of broadcasting facilities efficiently administered will be important to British prestige throughout the world." [1]

\section{Introduction}

The quotation above is taken from an internal memo from the BBC's then Director of Outside Broadcasts Seymour Joly de Lotbiniere to the Senior Controller of Programmes. It emphasized the importance to the $\mathrm{BBC}$ of its preparations to broadcast from the 1948 London Olympic Games. De Lotbiniere, commonly known as 'Lobby', was the BBC's 
Director of Outside Broadcasts from 1935 to 1940 and once again after the war from 1946 to 1955 . Lobby was an incredibly influential character in the history of sports broadcasting and was the BBC's general manager for their coverage of the 1948 Games. From 1935 he had devised a set of guiding principles for the BBC's coverage of sport on both radio and television that arguably endure today. The 1948 Games produced a landmark phase in his career and British sports broadcasting more generally. It signaled the emergence of a new relationship between the $\mathrm{BBC}$ and the governing bodies of sport. It produced a new scale of broadcasting operation in terms of the logistical and strategic planning required in the coverage of a major sporting event such as the Olympics. Finally, it also proved a key period in rekindling interest in the BBC's fledgling television service, suspended at the outbreak of war in 1939 and reintroduced in 1946. Understanding why coverage of the London Games proved to be such an important aspect of the BBC's programming in 1948 and how the managers and producers of the Outside Broadcasting department coped with the constraints of economic and political austerity are the focus of this article.

\section{In the shadow of war}

The wider social, economic and political context of the BBC's coverage of the Games was all-important. As recent histories of the immediate post-War period in Britain have acknowledged [2], there were long and strong shadows cast by the severity of war: there was the loss of US economic support crippling the UK economy still paying for the war effort; the constraining austerity policies of the new Labour Government and the continuation of rationing; and the drive towards nationalization of many utilities 
underpinned by Keynesian demand management. All these processes had an influence on the BBC. In spite of some detractors it maintained its position as a broadcasting monopoly and its news output was no longer under direct influence of the Ministry of Information. The BBC's Director General, Sir William Haley, was determined to assert the BBC's independence from the state after the war and at times during the immediate post-War period relations with the Attlee government were strained. [3] The BBC had gained respect for its informative role during the war. 'Like the nation', recalled Welsh broadcaster Wynford Vaughan-Thomas, it had 'stood up to the ordeal with courage and skill.' [4] Its programming had changed through the war, less about 'improvement' and more geared toward informing and entertaining in a stratified 'cultural pyramid'. During the war the BBC had increasingly responded to popular taste to "provide the listener with an element of choice without sacrificing the old Rethian seriousness of purpose'. [5] Under a new sense of freedom, programmes like It's That Man Again (ITMA) and The Brains Trust flourished and regularly drew 14 million listeners.

Sport had been marginalized during the war, dependent on 'significant degrees of initiative and improvisation' to keep it going between 1939 and 1945. [6] There had been an initial moratorium on sports broadcasts in the early phase of the War, Post Office line restrictions and petrol rationing severely restricted the Outside Broadcasting department and 'much of the glamour had gone out of such national sporting events'. [7] In spite of being 'heavily pruned' the $\mathrm{BBC}$ had reintroduced running commentaries on sport wherever possible. According to Asa Briggs the expansion was warranted on four grounds: it added greatly to the variety of broadcast material; it gave the public a 
'reassuring impression of normality'; there was much 'virtue in actuality'; and outside broadcasts dealing with topicality gave an impression of the BBC's resourcefulness and vitality. [8] The commentator Raymond Glendenning did much to convince the sporting authorities that sports broadcasting helped the morale of the forces and the British public [9]. Sports coverage did much in assisting the move from the 'cultural elitism' of preWar programming so favoured by the BBC's first Director General John Reith. [10] More broadly, the BBC Outside Broadcasts department advanced its reputation enormously during the war with live broadcasts from across Europe as reporters such as Vaughan-Thomas, Richard Dimbleby and Stewart MacPherson joined the Allied advance on Nazi Germany. In 1943, as the new Director of Empire Programmes, de Lotbiniere had been integral to the establishment and planning of the War Reporting Unit and the international transmissions from foreign fields, and many of the reporters would return in peacetime to commentate on sport. Arriving back in London fearing doom and gloom amongst general austerity Vaughan-Thomas commented: 'I found an Outside Broadcasts department which had been charged with a new dynamism by its war experience, and soon new colleagues came to join us, who each brought a new approach to the business of running commentary.' [11] These new recruits would include John Arlott, Brian Johnstone, Rex Alston and Max Robertson. Many of them had served in the armed forces. All would play their part in the coverage of the 1948 Olympic Games and go on to become the household names of broadcast sport in the 1950s and beyond.

Outside broadcasting, then, had been important for transporting the listener to the front line of the War and had innovated new ways of binding the audience to a common 
national cause. As Scannell and Cardiff note, radio 'gave the individual an unprecedented sense of himself as part of the larger community'. [12] In peacetime, broadcasts from sport and state occasions would prove the most immediate connection from the home to communal public life. The 1948 Olympic games would prove no exception, but it required immense planning on the part of the $\mathrm{BBC}$ to ensure both the nation and an international audience could share what was initially viewed as a most unlikely pageant of sport so soon after global war.

\section{Legacy and Lessons of Berlin, Helsinki and St. Moritz}

Even before the war was over Lord Aberdare, IOC member and Chairman of the National Association of Boys Clubs had indicated that the Games would return in 1948. [13] In a move to promote the ideals of the Games he approached the BBC through his friend Harold Abrahams with an idea for a talk on the Olympic movement and in January 1945 a script was written for the programme Sporting Record, then produced by Raymond Glendenning for the Forces Programme. The script dismissed the notion that 'the Olympic spirit is dead' and that the 'true spirit of sportsmanship' would return, 'avoiding the nationalistic twist which the Nazi Government gave to the 1936 festival'. However, the programme was never made, Michael Standing, the acting Director of Outside Broadcasts before Lobby's return, concluding, 'the subject could hardly be discussed without reference to the participation of our enemies in the next Games and we feel that that perhaps is not a matter best raised just at the moment'. [14] 
In February 1946 Lobby, now returned as Director of Outside Broadcasts, wrote to senior management in the BBC to announce, 'I have heard on a side wind that it is likely that before the month is out there will be an official announcement that the Olympic Games are to be held in this country in 1948'. [15] According to Lobby, Lord Burghley, Chairman of the Olympic Organizing Committee, would 'blow the gaff' at a press party held at six o'clock - just in time for the morning newspapers - and the BBC eager to get a scoop approached Burghley to make an announcement after the seven o'clock news that night.

With the Games confirmed the BBC set about planning their coverage. Internal economic pressures on the $\mathrm{BBC}$ were immense but the mood remained positive. If there was one overbearing external pressure it was to showcase the technological skills and organization of the $\mathrm{BBC}$ to their international visitors. There was a perception that the efforts of Lobby and his team would be judged in the context of the Nazi's efficient and technologically advanced media centre of 1936 that had introduced closed-circuit television. In the shadow of war, in an age of severe economic hardship, it was considered important for Britain to host the games successfully. For the BBC, the Games were a point of prestige, but also an opportunity to showcase how they thought outside broadcasting should be done.

In many ways the BBC had nothing to prove, its broadcasts during the war had been the main source of information to people in occupied nations across Europe. But in 1936 the 
Reich Broadcasting Company had accommodated an array of international broadcasters showcasing a limited television service.

In a rush to impress their visitors in 1936 the Nazi Party had been keen to innovate television coverage by transmitting several hours of each days events to selected venues. There was coverage from the main stadium and the swimming arena [16]. There were fewer than 1000 sets in the entire country almost all situated in public halls. [17] One venue included the Joy Village located near Funkturn where large screen television was part of wider entertainment that showcased German athleticism and culture. [18]

The Nazi's introduction of closed-circuit television had been judged an outright failure in some quarters. For one correspondent from The Times, the 'picture resembled a very faint, highly underexposed photographic film, and were so much worse than ordinary transmissions from a studio that many turned away in disappointment'. [19] An American journalist likened the images to 'humans floating in a milk bath'. [20] The different camera systems had not been synchronized and were prone to blackouts and were often too cumbersome to capture the fast moving action.

The BBC's athletics commentator at the 1936 Games, Harold Abrahams, gave briefings to other commentators based on the official film Olympia directed by Leni Riefenstahl. Distribution and exhibition of the film had been very restricted across Europe, but the British Olympic Association had purchased a print and invited Lobby and other members of the BBC's Outside Broadcast department to its screenings. Olympia was used to train 
the BBC's new crop of commentators in order to practice their commentaries on some of the more obscure events - to British eyes at least - and also for the television producers to consider ideal camera positions.

Other intelligence had also been gathered to assist the planning of the BBC's coverage. Some of the information came from unlikely sources. Lobby and the BBC engineers obtained plans for the 1936 broadcasts, as well as a blueprint for broadcasting the aborted Helsinki Games of 1940. They were acquired from a former BBC staff member Henry Riddell, one of the many British civil servants sent out to Berlin during the Allied occupation of the German capital immediately after the war. However, in the post-war devastation and with political division in Berlin, access to German documentation in the city was not easy. Although the Olympic Stadium was in the British quarter of the city the Russians had removed most of the Olympic library and documentation had been consigned to the Commission for Physical Culture in Moscow. [21] The Berlin Broadcasting House was in the heart of the Russian quarter and Riddell confessed, 'To enter Broadcasting House here is not easy for the British but I got my spies out and they did find one item in the library of Broadcasting House.' [22] It was the Radio Guide Book much cherished by Lobby. Riddell also included a pamphlet issued by the Organizing Committee of the 1940 Helsinki Games entitled Olympic News Service, providing much needed details of commentary positions, cabling, recording equipment and other technical requirements. The information was indicative of what would be needed for the coverage from Wembley. [23] Lobby wrote to thank Riddell for his detective work and hinted at the austerity in Britain in contrast to the devastation, subterfuge and political turmoil of 
Berlin at this time, remarking, 'I can imagine that you are having a pretty tough time in Germany. Things seem gloomy enough here but what it must be like there is, I expect, beyond the imagination of anyone who has not been over to see for themselves.' [24]

Our man in St. Moritz

As well as information from Berlin and Helsinki, the BBC also had first-hand experience of broadcasting arrangements for the 1948 Winter Olympic Games in St. Moritz, Switzerland. Staff commentator Max Robertson had covered the skiing, bobsleigh and the Cresta run for the BBC and clearly enjoyed his time in the Swiss Alps recalling in his autobiography that 'everything was new and shining' and the occasion took him 'away from the dreary rationing and petty restrictions of post-war Britain.' [25] However, his general impression of the event and its organization was altogether more glowing than that of his producer Konrad Syrop. His report suggested the Swiss organization was 'inefficient and unbusinesslike'. The facilities for broadcasters were far from what had been promised: 'The equipment, while supplied in considerable quantity, was untested, kept breaking down and was of a type unsuitable for the purpose.' All in all, the impression of the Swiss hosts was that 'their organization combined inefficiency with red tape and created chaos.' [26] The Swiss had clearly found the Games a burden and in the immediate run in to the London Games the Secretariat General of the Societe Suisse de Rediffusion, Mr. de Reading, wrote to Lobby to send his best wishes, but sarcastically concluded 'you have all my sympathy'. [27]

\section{Negotiation and Planning}


The 1948 London games proved a test of the BBC's Outside Broadcasts department's collective knowledge and strategic planning. It was without doubt the largest broadcast event the BBC had ever undertaken by that time and would arguably prove to be an invaluable experience in the planning of the Coronation in 1953, recognized by broadcast historians as a landmark event in the social history of British television that popularized the new medium [28].

The 1948 Games came at a crucial time in the development of outside broadcasting as sport producers aligned theircoverage with the wider light entertainments policy emerging at the BBC. From 1946 sport was to form a central aspect of the new entertainment policy, given added impetus by Haley. Conscious that broadcasting was entering a new phase of development and that the BBC's monopoly was under the spotlight from government and the wider public (the license fee had doubled to $£ 1$ after being static for 24 years), Haley believed that raising the standards of the $\mathrm{BBC}$ would never be successful unless its broad contract with the listener included entertainment. Sport entered into the lexicon of light entertainment and was predominantly broadcast on the BBC's Light Programme. As negotiations for the 1948 Games would show, the value of sport to the BBC would soon begin to pull harder on resources. Sport was key in attracting and maintaining listeners and the $\mathrm{BBC}$ would be neglecting its duty of entertaining its audience 'if it disregards that part of its triple function'. [29]

Finance and Rights Fees 
Financing the coverage of the games was of grave concern. As the drive to expand the scale of entertainment and outside broadcasts moved ahead, it was to be achieved in a stricken economy. Haley had reeled in expenditure across the BBC and at the height of the fuel crisis in February 1947 the BBC's television service was pulled off the air in order to save money before resuming its modest service in April of the same year. As one of the BBC's chief engineers, Robert Wood recalled:

The $14^{\text {th }}$ Olympic Games put a huge strain on our resources. Everything was still being done on a shoe-string, but now - used to all that radio could do - people expected more and more of us, unaware of the technical shortages we faced. [30]

Initially, as early as October 1946, Haley and the Acting Controller of the BBC, R. J. F. Howgill had agreed that Lobby and the OB department move ahead with plans for the $\mathrm{BBC}$ to undertake the entire broadcasting arrangements of the games themselves, shouldering the whole cost with a request that estimated costs be provided in due course. [31] Moreover, the Director General had also opened negotiations with the newly formed Society for the Protection of Copyright in Sport - acting as a trade body on behalf of the governing bodies of sport in negotiations over broadcasting coverage - and it was agreed that the London Games fell outside the ordinary run of sporting events and additional fees would be paid. These were facility fees and not intellectual property rights or 'broadcasting rights', but it is worthwhile noting that payment to cover the games was being established as a matter of course. 
By the end of 1946 Lobby had set about opening up lines of communication with the Organizing Committee and had begun the thorny task of providing a financial estimate upon which a final budget could be arrived. Lobby favored more reticence regarding the BBC's commitment. Facilitating the entire broadcasting arrangements for the $\mathrm{BBC}$ and all visiting broadcasters was a daunting undertaking. His concern was well founded. The BBC had never been involved in such a large-scale outside broadcast with multiple venues, simultaneously serviced to multiple international broadcasters. In December 1946 he wrote:

I see one difficulty ahead in that we should not finally commit ourselves to financing all the broadcasting facilities until we know what the bill will be, and it will be a good while before that can be worked out. I should not be at all surprised to find the bill would be of the order of $£ 50,000$ or more - to judge from Engineering division’s $£ 12,000$ estimate for the South African tour. [32] Indeed, BBC engineers did not provide a full estimate until spring 1947 revealing the true nature of the resources required.

According to the engineer's first list of 'approximations of likely expenditure' the entire cost of the building works, purchasing of equipment and labour would be near $£ 130,000$. [33] The engineering division also requested that the $\mathrm{BBC}$ retain all of the 104 members of staff in post, enforcing the stoppage of any divisional leave throughout the duration of the Games and reducing the BBC's commitment to all other outside broadcasts by at least 50\%. [34] The escalating costs were initially met with horror by Haley, who instructed Lobby to reduce the estimate by $25 \%$ occasioned by reducing the level of service 
(reducing the number of microphone positions, for example) and renewing negotiations with the Organizing Committee regarding sharing the burden of providing a radio centre to host international broadcasters. Haley was himself called upon to privately negotiate the cost of access to Wembley and other venues, meeting Lord Portal, the Chairman of the Olympic Organizing Committee in April 1947, where it was agreed that the BBC would provide remuneration for the loss of income in ticket sales. The BBC's plan was to have fifteen commentary booths, seventeen open microphone positions and a further one hundred seats for visiting broadcasters taking up a total 330 of the best seats in the stadium. The estimated price was $£ 12,000$ and Holt, the director of operations for the games agreed that the 100 seats could be given free (worth an estimated $£ 3,150$ ).

Although Lobby had conducted site visits and had begun, somewhat tentatively, to estimate the cost of the operation, with little over twelve months to go, very little building work had yet taken place. A large part of the building works for the games fell to Sir Arthur Elvin, owner of Wembley Stadium. The BBC emphasized the need for sufficient accommodation near the stadium in a building that could house a range of technical, operational and informational needs. Perhaps realizing the scale of operations and the reticence of the $\mathrm{BBC}$ to stretch their escalating budget still further, Elvin agreed to lease the Palace of Arts, built as part of the 1924 Empire Exhibition, as the venue for the Radio Centre. The BBC would have to pay for the renovation of the building and in July 1947 a revised budget was presented that skirted close to $£ 200,000$. Haley, now resigned to the prospect of paying facility fees, a substantial investment in technology and the capital expenditure of building works demanded one final attempt at sharing the costs of 
building the Radio Centre. For, as a memo from the Senior Controller Nicolls to Lobby suggested he was, 'doubtful as to whether we can get away with not paying for the seats at Wembley' but doing so might act as a 'bargaining factor in relation to their paying for the building work'. [35]

From the archival evidence, the prospect of passing on the cost of the building work to visiting broadcasters who stood to benefit from their construction does not appear to have been raised. The point is important when we reflect on the overtly commodified spaces of television and sport in the contemporary Olympic regime: the inflated rights fees and the technological and operational costs.

Unfortunately for the BBC, by autumn 1947 it was clear that the Organizing Committee severely starved of resources themselves (the cost of hosting the Games was close to $£ 700,00$ and Wembley itself ran at a loss of $£ 200,000$ ) would not relent. In a stinging memo to Haley, Nicolls, wrote: 'we had vague assurances from them in the early part of the negotiations that they would build the Radio Centre for us, on which they have now ratted!' [36]

While Nicolls' rage may have been well founded, the responsibility and cost of hosting the broadcast facilities for the Games squarely fell in the lap of the BBC. Arguably, in1948 we saw the first instance of broadcasters carrying some of the burden of the Games as a global media event. 


\section{Hosting the Olympic Broadcasts}

The fifteen-day sports extravaganza would consist of 136 events in thirty locations with competitors from fifty-eight nations. In a draft script for a Broadcasting Handbook for visiting media Lobby highlighted the challenge these figures presented:

Take another look at those few statistics and then try to imagine how they affect the $\mathrm{BBC}$ which not only has to provide its own coverage of the Games in more than 40 languages, but which has to supply for all-comers the necessary outside broadcasting facilities. [37]

In the event, the $\mathrm{BBC}$ catered for 250 broadcasters from 60 different radio stations and apart from initial chaos on the opening day the coordination of the technological services and hospitality of the $\mathrm{BBC}$ was well received. In planning the use of the facilities the great unknown was precisely how many of these broadcasters would want to cover any given event, whether it would be 'live' or recorded, what language they would be transmitting in and whether or not broadcasters would want to link commentators from different venues. As Lobby wrote in August 1948, in his first official report of the broadcasting organization at the Radio Centre:

[The Centre was] a consulting ground where producers could take advice from the engineers on the best way of overcoming problems of lines of communications and where the technical staff could make use of the linguistic knowledge of the $\mathrm{BBC}$ producers who were pulling together the story of the Games for all the countries of the world. [38] 
This sense of camaraderie between hosts and visitors is probably no coincidence so soon after the sacrifices of war. It echoed a wider sense of comradeship across the Games in the face of economic hardship and austerity. As Brian Glanville later reflected:

Looking back from this vantage point in time at an event, which excited one as a schoolboy, one can see that there was, about these 1948 Games, a certain, almost primeval, innocence. The very improvisation of it all, the very limitation of events and athletes, the very absence of the ultra-organized, deeply professionalized, Iron curtain teams, gave the Games a dewy allure. [39]

The notion of getting along, adapting to situations and working things out characterized both the Games and the efforts of the broadcasters. Lobby had also been keen to mirror the services enjoyed by the press corps and requested a bar to be installed in the Radio Centre. After much protracted negotiation over a license a bar was installed to provide an area for relaxation and socializing for host and visiting broadcasters alike.

\section{Black Friday}

The Games opened amid chaos for BBC managers and was soon labeled 'Black Friday'. The Radio Centre found itself handling heavy bookings from Wembley and as the timetabling of events got progressively worse with the afternoon session starting 35 minutes late, the $100 \mathrm{~m}$ heats taking one hour instead of 30 minutes and the high jump running over by an hour, the changes caused enormous problems. Visiting broadcasters had pre-booked allotted slots on one of the 36 channels emanating from the mixing desks housed in the Palace of Arts and found their slots were no longer congruent with the 
action on the track. Peter Dimmock, then a young television producer, recalled the reason for the delays:

I was looking after the television and Lobby was masterminding the radio. Radio was a real headache for the Olympic Games and he was masterminding that. They discovered, right at the very beginning, that they hadn't measured the track right. So they had to stop everything and re-measure it, and adjust it. That threw all the overseas transmission times out of kilter. And Lobby had to sort that lot out. [39]

Planned bookings were rescheduled and the management of multiple broadcasters with different languages and different needs became too much to handle. Lobby later reflected, 'We had not realised how many technical operations would be affected by the changes', he continued, 'one or two broadcasts became casualties'.[41] The inauspicious start to broadcasting the Games meant some quick lessons were learnt. A quota of microphone positions were tied in to recording channels in order that no future events would be missed and meant less switching within the control room between overseas broadcasters.

\section{The World Listens In}

The planning and coordination of overseas broadcasts had been meticulous and jointly managed by Lobby and Konrad Syrop, Assistant Head of European Broadcasts within the BBC's Overseas Department. In a report of the broadcasting operation for the BBC Board of Governors the sheer scale of the operation became apparent. 1545 transmissions from Wembley Stadium, 525 of these were to Europe, 225 to North and South America. 
There were 2622 recordings of commentaries, interviews and eyewitness accounts, using 6066 discs. The BBC dedicated 750 staff to the Games, including 300 engineers, 250 commentators and 200 other staff whose 'devotion to duty', Lobby wrote, 'took no account of long hours and exacting work.' [42] Many staff worked double shifts to service the needs of the international visitors whose 35 daily broadcasts kept the BBC's lines open up to 15 hours a day. The BBC's General Overseas Service operating outside Europe produced five 15 minute 'Olympic Reports' each day and produced nearly 29 hours of programming for its international audience. North American broadcasts totalled 34 hours 25 minutes, South American nations received 30 hours of coverage.

The scale of the event and the international broadcasts had a dramatic effect on audiences around the world. The transmissions had included the first international broadcast to Korea and in the Olympic report by George Looter for the BBC's General Overseas Service he reprinted a translation of a letter sent to the Korean commentator Min Chai Ho of the Korean Broadcasting system from his wife. It read:

I heard your voice from London last night. Before the broadcast started, I was very anxious because the test broadcast last Friday was not a success; and also it was very dark when I listened because the electricity was off. But at 11.45 when the electricity came on, all the town was filled with your voice and I could not help crying. You are a very long way away, many thousands of miles over land and sea, but still I can hear your voice just as though you were sitting beside me. [43] 
There is pathos within this simple letter from a wife to her husband working thousands of miles away. It reveals the unstable first steps of a new, increasingly global, communications technology. The world was being connected in new ways through the combined power of the internationalisation of sport and broadcasting. It reveals the unstable nature of life still recovering from war. But most importantly, it reveals the power of the immediacy of broadcast sport, particularly international sport that is delivered from the other side of the world but in a familiar voice that connects with a national audience and culture.

\section{Television}

The sense of experimentation and the constraints of resources were felt most strongly in the BBC's attempts to televise the Games. Before the War the BBC had rushed to introduce a public television service in 1936, neither fully appreciating the lack of demand for the technology, nor the manufacturers unwillingness to innovate new markets. [44] With barely 20,000 television sets sold the service was suspended in 1939 at the outbreak of War. With the resumption of television in 1946 the BBC's approach to the medium remained one of managerial and financial restraint. There were only 80,000 television licenses in 1948, with an estimated audience of half a million, most located in a forty-mile radius of London. As far as the BBC were concerned there could certainly be no grounds to fear that televising the Games would affect attendances at Olympic venues.

\section{Television access and facility fee}


In 1948 television still played second fiddle to radio by some margin. It received only one tenth of the budget that radio enjoyed, and even senior managers were not convinced of its strengths. Dimmock who had joined the $\mathrm{BBC}$ after a brief career as a racing correspondent with the Press Association reflected on television's status at this time: It was very exciting. But of course we were totally looked down on by radio. Radio didn't give us any money. They thought we were just a stupid lot of peep show boys at Alexandra Palace. They thought of us as the film world, nothing at all to do with radio. Radio was respectable. [45]

The perception that television equated with film did pose problems for the BBC. Newsreel companies whose magazine approach to the coverage of sport had become very popular during the Inter-War years now faced competition [46]. The Rank Organization had bought rights to film the Games for $£ 20,000$ and was highly protective of their exclusive agreement. BBC Television outside broadcasts were managed by Ian OrrEwing (later Lord Orr-Ewing) and his initial meetings and reconnaissance of the stadium had been conducted in March 1947 when the thorny issue of rights fees had been raised. In the context of spiraling costs Lobby was scathing of the idea. In a memo to Orr-Ewing he wrote: 'I said then that we were one organization and that if we were putting our hand deep into our pocket to provide broadcasting facilities for all-comers we might not wish to put it deeper still in order to pay a television fee as well.' [47]

The issue rumbled on and by November 1947 Nicolls reiterated the point that 'Wembley has no right in the image that appears on our television receivers' and that any payment 
would be for 'goodwill and access.' [48] The BBC had maintained the view that paying a facility fee was acceptable on the grounds of lost revenue from gate receipts. But a 'rights fee' suggested a different kind of commercial relationship and a grey area as far as the law of copyright was concerned.

The Organizing Committee had no objection to live television, but filmed material relayed by television was a different matter. For 'if the public can at their convenience see television versions of the Games', Holt wrote to Haley, 'they will not leave their homes and go to the cinema to see the feature film.' [49] The edict was perceived as damaging to a fledgling technology. The BBC had also made arrangements with NBC in the United States to distribute television newsreels across the Atlantic. The news of the rights wrangle had reached the Americans who threatened to make a formal diplomatic protest against the exclusive deal. In a plea that made great play of the world's perception of Britain the Head of Television Service, Norman Collins, drafted a response on behalf of the Director General that recognized some private sports events may wish to exclude BBC Television but submitted that 'the Olympic Games fall within a different category and, being international in character and representative of Britain by virtue of taking place within this country, should not become an exclusive commercial property'. [50]

The statement was a precedent to future arguments between the BBC and the governing bodies of sport over the coverage of major sports events that would ultimately lead to non-exclusivity clauses around a series of 'listed events' that would include the Olympic Games. Haley lobbied the Commonwealth Relations Office laying emphasis on the 
importance of television newsreel to the BBC's 'social developments in the field of broadcasting'. [51] By the end of January 1948 the matter had been resolved in a meeting between Haley and Lord Portal, with the BBC agreeing to present newsreels simultaneously with Rank's cinematic release and a 'gentleman's agreement' that any recordings 'off tube' would remain private to the $\mathrm{BBC}$ and not publicly available. A fee of $£ 3000$ was agreed but it is unclear from the archives whether or not this payment was made.

\section{Televising the event}

The Games presented new challenges for the presentation of sport. Orr-Ewing had studied the camera positions of Olympia at the 1936 swimming events and noted the camera angles of the pool were too low to enable viewers to identify the swimmers. The camera at the pool was duly raised higher in the stands to capture the event properly. The BBC had bought new Marconi Emitron Cameras and planned to have three cameras inside Wembley Stadium and the fourth positioned outside to capture the thousands of spectators as they walked along Wembley Way giving a wider perspective of the event.

The BBC transmitted 64 hours of programming, including one seven and a half hour stretch on one day. In spite of a few words of encouragement from athletes, viewers and the press the technology had its limitations. The CPS Emitron cameras were British and inferior to the technology developed through the war by the Americans. According to Dimmock this was one area where British wasn't best: 
I was fighting our engineers all the time, saying, 'we've got to get rid of this British equipment. I'm sorry, I'm very British, I'm very loyal, but it doesn't bloody work!' The moment the light went down the picture would peel off from the left hand corner. [52]

Knowledge of how the cameras worked and how to produce the best picture with the limited resources was key to the operation. For this reason the $\mathrm{BBC}$ devised a method of using producers as commentators, in order to both save money and have a skilled hand on site to manage a situation when things went wrong. Again, as Dimmock explains: It sounds ludicrous now. We couldn't have a camera more than $300 \mathrm{ft}$ from the control van because that was the length of the cable. We couldn't have a cable that was longer than that. So that made it very difficult with putting the camera positions in. We didn't have enough cameras, but we did the pool and the main stadium. What we did was we produced and commentated. I did a lot of swimming commentaries. I didn't know a lot about swimming, I knew a little bit about it. We alternated. Then I did some show jumping, and I'd produce and commentate. But we were real 'jacks of all trade' really. [53]

Television commentators and specialists had been trained for weeks. Jack Crump commentated and acted as athletics advisor; Peter Wilson, a sports journalist, covered boxing with Colonel Dudley Lister; Freddie Milton was the specialist on swimming alongside John Webb on diving; and former referee Jimmy Jewell did the football commentaries. 
Three mobile units were in use coming from locations that demanded rapid interswitching between Wembley Stadium and the Empire Pool. In all 56 events totaling 34 hours were televised from the Stadium and 52 events including swimming and boxing made up a further 26.5 hours of programming.

According to the BBC's own report the highlights of their television coverage included the opening ceremony with commentary from the imperious Richard Dimbleby. However, according to the report the 'most poignant moment for viewers came at the end of the marathon' as telephoto lenses followed the three leaders round the track as the 'tottering' Belgian leader Etienne Gailly was passed by the Argentinean Delfo Cabrera and Tom Richards of Great Britain. Other drama included the Jamaican Arthur Wint who pulled up in the final stages of the 4 x 400 metres relay, that commentator Max Robertson remembered as a 'very painful and frightful moment' [54]. In the immediate post-war period the conditioning of athletes was clearly not as good as it might have been and led to Danish swimmer Greta Anderson catching cramp and 'rescued from drowning under the very eye of the camera.' Such live action and drama on screen was revelatory as was the ability to pull athletes straight from their events in front of the cameras for an interview. Both British athletes Maureen Gardner and the Dutch sensation Fanny Blankers-Koen were brought to the cameras immediately after their duel in the 80 metres hurdles, both having broken the Olympic Record. In the pool forty swimmers faced the cameras including Britain's Cathy Gibson, 'who made an astonishing television picture in the 400 metre free-style race as she battled from seventh place to third'. [58] The BBC 
report makes great play of the fact that many of the swimmers 'were televised while still wet', a sign that the immediacy of television, to graphically reveal sporting events as they happened was revelatory, not only for the audience, but for the BBC too.

\section{Reactions to the $\mathrm{BBC}$ Coverage}

The information on radio and television audiences for the 1948 Games is pretty thin. The BBC did record some reactions through its Audience Research Unit and there is anecdotal evidence from the correspondence of sports administrators like Elvin that the BBC's coverage and organization 'did much to boost our Country throughout the World'. $[56]$

The BBC's Overseas Audience Research received eighteen letters with reference to the Games that suggested interest had 'been at a lower level than the Test Matches'. [57] Criticisms were scarce but the report highlights one complaint that the BBC's radio coverage of the opening ceremony had revealed an ideological bias by omitting to mention the Spanish Team and it was hoped that 'the BBC broadcasters will on no occasion mar accounts of the proceedings by any discourtesy towards nations for whom they are in the habit of exhibiting a distaste.' [58]

Television monitors had been strategically placed in the Radio Centre and the athlete's village. This tactic appears to have paid off, certainly according to a glowing report in the BBC's Radio Times shortly after the Games: 
There seems to be general agreement that it [BBC television] acquitted itself even better than had been expected. Everywhere we went during the period of the Olympiad we heard admiring comments on the technical excellence of the transmissions. Enthusiasm was perhaps greatest among the competitors and officials from overseas who were watching television programmes for the first time, but seasoned viewers were also astonished by the results achieved. [59]

Unfortunately, 1948 was too early for 'telerecording' and no footage of the televising of the Games survives for historians to pass judgment. But clearly, even among a very modest audience, television left a lingering impression. Haley received letters commending the technical achievement of televising the Games. F. C. How of the Ministry of Supply commented on the success of British television, 'I am not often moved to write to the BBC, but I feel that I must offer to you and all concerned my congratulations' [60] Haley responded:

I got some idea of the impact of this even in Devon where, at the hotel I was staying at, newcomers from London, not knowing who I was, were talking about little else except their excitement at having seen the Olympic Games on television in their own homes. Like you, I hope that people going back to their own countries will carry word of what British television has shown it can do. [61]

News of such complimentary words from London's 'chattering classes' would have impressed BBC senior management. Although television would not truly make its mark 
until the Coronation in 1953, the hegemonic grip of radio would have been loosened by such comments.

\section{Conclusion}

The archival written evidence for the 1948 Games provides an insight into a seminal era of experimentation in sports broadcasting, particularly in television. De Lotbiniere along with an emerging specialist team of broadcasters guided the $\mathrm{BBC}$ to a memorable phase in its development as a public service broadcaster. The role of television in connecting the wider public to international sporting rituals like the Olympics is now embedded in our popular culture. Today it is driven by commercial and entertainment concerns, in 1948 it was largely driven by the ideology of the games itself, a desire to prove Britain could host the Games in spite of the austere environment and the public service ideology of the $\mathrm{BBC}$ - something it continues to draw upon in its rhetoric regarding the license fee and its continuation as a part of British cultural life. In their social history of broadcasting Cardiff and Scannell argue that at times of public ritual, such as royal ceremonies or sporting occasions, television can 'provide a fragmented audience with a common culture, an image of the nation as a knowable community' [62] In 1948 one could have certainly made this argument for radio but not television. The rehearsed ceremonial and ritualistic elements of the Games combined with the wider post-War social and economic context of austerity to create a shared sense of achievement in hosting the Games. This, at least, appears to be the aim of the organizing committee and also of the BBC's approach to covering the Games and hosting international broadcasters. No matter that British athletes had failed to win any gold medals. Hosting the Games and international 
broadcasting had shown Britain at a liminal point between the devastated world created by the war and the seeds of a materially new modern world, represented by television, globalization and the spectacle of modern sport.

The esprit de corps of wartime carried forward in the outside broadcasting department's approach to managing the coverage of the Games, both domestically and overseas. Britain's reputation, its very ability to look forward and 'be modern' were at stake and under inspection. The evidence from the BBC Written Archives suggest the coverage of the 1948 Olympic Games, although passed over in many histories of British broadcasting, were significant in showing the power of sports broadcasting to bring communities together, even under severe economic and social conditions.

\section{Notes}

[1] De Lotbiniere to Nicolls, 27 May 1947. BBC Written Archives Centre (WAC), $\mathrm{R} 30 / 2,066 / 1$.

[2] See Hennessy, Never Again: Britain 1945-51; and Kynaston, Austerity Britain 19451951.

[3] Smith, 'The struggle for control of the air-waves: the Atlee governments, the BBC and industrial unrest, 1945-51'.

[4] Vaughan-Thomas, Trust to Talk, 145

[5] Scannell and Cardiff, 'Broadcasting and National Unity', 67

[6] Baker, 'A more even playing field? Sport during and after the war', 134 
[7] Briggs, A History of Broadcasting in the United Kingdom: Sound and Vision. Volume

4,97

[8] Briggs, 98

[9] Booth, Talking of Sport: The Story of Radio Commentary.

[10] Nicholas, 'The People's Radio: The BBC and It's Audience 1939-1945', 63

[11] Vaughan-Thomas, 188

[12] Scannell and Cardiff, 66

[13] Hampton, The Austerity Olympics: When the Games Came to London in 1948, 22

[14] Standing to Aberdare, 2 February 1945. BBC WAC, R30/2,060/1.

[15] De Lotbiniere to McGivern, 8 February 1946. BBC WAC, R30/2,060/1

[16] Large, Nazi Games: The Olympics of 1936, 250-51

[17] Uricchio, 'Introduction to the history of German television, 1935-1944'.

[18] Large, 204

[19] 'Television of the Games Disappointing Result', The Times, 3 August 1936.

[20] Large, 251

[21] Riddell to de Lotbiniere, 24 February 1947. BBC WAC, R30/2,056/1.

[22] ibid.

[23] Berlin 1936 had 20 boxes, 15 open microphone positions and 77 seats; Helsinki 1940 planned to have 16 boxes, 12 open positions plus an unaccounted for number of seats; and London 1948 had 12 boxes, 12 open microphone positions and 100 seats in Wembley Stadium.

[24] De Lotbiniere to Riddell, 6 March 1947. BBC WAC, R30/2,056/1

[25] Robertson, Stop Talking and Give the Score, 58-59 
[26] Syrop to Director of Overseas Service, 12 February 1948, BBC WAC, R30/2, 046/2.

[27] De Reading to de Lotbiniere, 26 July 1948. BBC WAC, R30/2056/3.

[28] Scannell and Cardiff.

[29] cited in Coase, British Broadcasting: A Study in Monopoly, 175

[30] Wood, A World in Your Ear: the broadcasting of an era, 1923-1965,

[31] Howgill to de Lotbiniere, 8 October 1946. BBC, WAC R30/2,066/1.

[32] De Lotbiniere to Howgill, 4 December 1946. BBC WAC, R30/2,066/1.

[33] Assistant Chief Engineer to de Lotbiniere, 22 April 1947. BBC WAC, R30/2,066/1.

[34] ibid.

[35] Nicolls to de Lotbiniere, 10 July 1947. BBC WAC, R30/2,046/1.

[36] Nicolls to Haley, 10 October 1047. BBC WAC, R30/2,066/1.

[37] ‘Olympic Games’, BBC WAC, R30/2,056/2.

[38] 'First report on the BBC Olympic Games Broadcasting Organisation At Wembley', 16 August 1948. BBC WAC, R30/2,046/1.

[39] Glanville, Wembley 1923-1973, 66

[40] Interview with the author, 12 May 2008

[41] 'Olympic Games Broadcasting Organisation at Wembley, 16 August 1948. BBC WAC, R30/2056/3.

[42] De Lotbiniere, Report on Olympic Games Broadcasting Operation', 3 September 1948. BBC WAC, R30/2056/3.

[43] Report of Overseas (Non-European) Coverage of the Olympic Games, 20 August 1948. BBC WAC, R30/2046/1.

[44] Winston, Media Technology and Society: A History, 113-114 
[45] Interview with author, 12 May 2008

[46] Huggins, 'Projecting the visual: British newsreels, soccer and popular culture 191839 '.

[47] De Lotbiniere to Orr-Ewing, 18 March 1947. BBC WAC, R30/2,066/1.

[48] Nicolls to de Lotbiniere, 10 November 1947. BBC WAC, R30/2,066/1.

[49] Holt to Haley, 30 December 1947. BBC WAC, R30/2,066/1.

[50] Collins draft letter, 2 January 1948. BBC WAC, R30/2,066/1.

[51] Haley to Noel-Baker MP, 7 January 1948. BBC WAC R30/2,066/1.

[52] Interview with the author, 12 May 2008.

[53] Interview with author, 12 May 2008.

[54] Robertson, Stop Talking and Give the Score, 69

[55] Television and the Olympiad. BBC WAC, R30/2056/3.

[56] Elvin to de Lotbiniere, 20 August 1948. BBC WAC, R30/2056/3.

[57] Audience Reaction to Olympic Games Broadcasts. BBC WAC, R30/2056/3.

[58] Television and the Olympiad, BBC WAC, R30/2056/3.

[59] Radio Times, 20 August 1948.

[60] How to Haley, 9 August 1948. BBC WAC, R30/2,066/1.

[61] Haley to How, 1 September 1948. BBC WAC, R30/2,066/1.

[62] Scannell and Cardiff, 168-9

\section{References}

Baker, N., 'A more even playing field? Sport during and after the war', N. Hayes and J. Hill eds. Millions Like Us? British Culture in the Second World War. Liverpool:

Liverpool University Press. 1999. 
Briggs, A., A History of Broadcasting in the United Kingdom: Sound and Vision. Volume 4. Oxford: Oxford University Press. 1978.

Booth, D., Talking of Sport: The Story of Radio Commentary. London: SportsBooks. 2008 .

Cardiff, D. and P. Scannell, 'Broadcasting and National Unity', J. Curran, A. Smith and P. Wingate eds. Impacts and Influences: Essays on Media Power in the Twentieth Century. London: Routledge. 1987.

Glanville, B. ed., Wembley 1923-1973. London: Kelly. 1973.

Hampton, J., The Austerity Olympics: When the Games Came to London in 1948. London: Aurum Press. 2008.

Hennessy, P., Never Again: Britain 1945-1951. Harmondsworth: Penguin. 2006.

Kynaston, D., Austerity Britain 1945-1951. London: Bloomsbury. 2008.

Large, D. C., Nazi Games: The Olympics of 1936. New York: Norton and Company. 2007.

Nicholas, S., 'The People's Radio: The BBC and It's Audience 1939-1945', N. Hayes and J. Hill eds. Millions Like Us? British Culture in the Second World War. Liverpool: Liverpool University Press. 1999.

Robertson, M., Stop Talking and Give the Score. London: Heinemann. 1987.

Smith, J. D., 'The struggle for control of the air-waves: the Atlee governments, the BBC and industrial unrest, 1945-51', in T. Gorst, L. Johnman and W. S. Lucas eds. Postwar Britain 1945-64: Themes and Perspectives. London: Pinter. 1989.

Vaughan-Thomas, W. Trust to Talk. London: Hutcheson. 1980.

Uricchio, W., 'Introduction to the history of German television, 1935-1944', Historical Journal of Film, Radio and Television 10: 2 (1990): 115-122

Winston, B., Media Technology and Society: A History: From the Telegraph to the Internet. London: Routledge. 1998.

Wood, R., A World in Your Ear: the broadcasting of an era, 1923-1965. London: Macmillan. 1979. 